\section{New IGCP projects accepted and starting in 1995}

Including the new projects that have just started in 1995, the IGCP is currently funding 51 projects. One project is on extended term.

\section{Project 347:}

\section{Correlation of}

\section{Ganges-Brahmaputra sediments}

Quaternary stratigraphic correlation of Ganges-Brahmaputra sediments and of the Indian Subcontinent.

\section{Proposer}

Md. Hussain Monsur

Department of Geology,

University of Dhaka,

Dhaki- 1000 . Bangladesh

The Ganges delta basin exhibits a thick sedimentary sequence of Quaternary deposits. Little work has so far been done on the stratigraphy, sedimentology, dating and regional correlation. The aims of the project are to establish the Quaternary stratigraphy of different geomorphic units, to demarcate the Palaco-Pleistocene boundary and to correlate the lithostratigraphic units with the chronostratigraphic scale of the Quaternary System by dating, using methods of litho-, bio-, pedo- and magneto-stratigraphy. These studics will infer regional Quatemary climatic fluctuations and sea-level changes and will be helpful in some practical, engineering and hazard mitigation applications.

The project is accepted for 5 years provisionally (1995-1999).

\section{Project 354: \\ Economic superaccumulations of metals in the lithosphere}

Environments, associations and processes of metal superaccumulation in terrestrial ore deposits and districts.

Proposers:

Pei Rongfu, P Lárnicka, J Kutina, D V Lundquist, C J Hodgson and Takeo Sato

Pei Rongfu,

Inslitute of Mincral Deposits.

CAGS,

26 Baiwanzhuang Road

Beijing 100037, P R China

Metals in the lithosphere are unequally distributed. Localised anomalous concentrations and accumulations of various metals that could be profitably exploited by past or present technological means have developed into 'classical' ore deposit categories. The aim is to provide the scientific base for explaining the processes and conditions of formation of existing giant ore deposits and hence to predict undiscovered equivalents. The current access to improved databases and an enhanced degree of international collaboration will provide real advances leading to the publication of a significant final volume and a global metallogenic map.

The main methodology will be information processing and statistical analysis, coupled with field meetings and workshops based on critical super-giant deposit localities.

The project is accepted for 5 years (1995-1999)

\section{Project 368: \\ Proterozoic events in east Gondwana}

Proterozoic events in cast Gondwana: southeast Africa-Madagascar-India-Sri LankaAntarctica-Australiat.

\section{Proposer:}

Masaru Yoshida

Department of Geosciences.

Faculty of Science, Osakat City University.

Sugimoto 3-3-138, Sumiyoshi-ku.

Osaka 558, Japan

Detailed studies of Precambrian terranes of east Gondwanian crustal fragments have been conducted by many scientists but detailed geological comparison of those fragments has been studied only brielly. The main objectives of the project are:

1 to investigate in detail and to correlate tectonothermal events with their culmination during about $2.5 \mathrm{Ga}$ and 0.5 Ga in east Gondwanian crustal fragments including south-eastern Africa,

Madagascar, India, Sri Lanka. Antarctica and Australia;

2 to obtain detailed P-T-t-deformationspace figures of some Proterozoic mobile belts and constrain their role in the tectonics of mobile belts and continents in east Gondwana, and

3 to clarify the distribution of selected mineral resources and to study its redistribution mechanism during the reworking of crust.

The project is accepted for 5 years (1995-1999).

\section{Project 379: \\ Karst processes and the carbon cycle}

World correlation of karst processes and its relevant carbon cycle.

Proposer:

Yuan Daoxian

The Institute of Karst Geology

CAGS.
Guilin-Guangxi.

P R China 541004

The role of carbonate rock dissolution or disintegration in the $\mathrm{CO}_{2}$, sink-source cycle in the atmosphere or the potential of karst records in high resolution palaeoenvirommental reconstruction have not been properly addressed yet in the fields of both global change studies and karstological studies. The scientific objectives of thi project as a successor of IGCP-299 (Geology, climate, hydrology and karst formation), are to concentrate on the understanding of the contribution of karst processes (dissolution) atmospheric $\mathrm{CO}_{2}$. and, to compare it volumetrically with $\overline{\mathrm{CO}}$ derived from other geological processes geothermal, volcanic and tectonic events. It will contribute to our understanding of climatic change after the late Pleistocene, in particular, to the biggest karst areas of the world, e.g. south China, south-east Asia, and south-west Australia.

The project is accepted for 5 years (1995-1999).

\section{Project 380:}

Biosedimentology of microbial buildups

Correlation of biosedimentology of stromatolites. mud mounds. and related microbial buildups in the Precambrian and the Phanerozoic.

Proposer:

C L V Monty

Laboratoire de Biosédimentologie,

2 rue de la Houssinière.

44072 Nantes Cedex 03. France.

Recent work on microbial structures encourage further studies. Multidisciplinary research will lead to detailed understanding of the nature, origin, genesis and signilicance of major types of microbial buildups (stromatolites, thrombolites. microbial boundstones, microbial reefs, reef mounds and mud mounds), which appeared in earth history as a result of the evolution of life and of the biosphere; marine and nonmarine stromes will be contrasted. Special attention will be placed on modelling living stromatolites with transfer of data, concerning the growth dynamics and the morphologies, to the past.

The project is accepted for 5 years (1995-1999).

\section{Project 381: \\ South Atlantic Mesozoic correlation}

Geological correlation of south Allantic

Mesoroic sequences

Proposers:

E AM Koutsoukos' and P Bengtson 2

${ }^{1}$ Petrobras CENPES/DIVEX/SIEBIPE 
Cidade Universitaria, Quadra 7

llha Do Fundau

21949-900) Rio de Janeiro RJ

Brazil.

${ }^{2}$ Geologisch-Palaontologisches Institut der

Universital Heidelberg.

1)-69120) Heidelberg, Germany

The main objectives of the project are to promote interdisciplinary geological correlative studies in order to establish a well-delined standard stratigraphical scale for the Mesoroic sedimentary basins of South Atlantic. The project aims at improving our understanding of the nature and sequence of major geological event during the formation of the South Atlantic and the global impact of these events, thus also contributing significantly to the exploration of hydrocarbon and mineral resources in the area. One of the major expected accomplishments of the project is the encouragement of a wide range of multidisciplinary activities involving a large group of scientists from developing countries, and stimulating postgraduate students (in particular from Latin America and Africal to undertake specific studies for MSc and PhD degrees within the framework of the project.

The project is alcepted for 5 years $(1905 \ldots 1999)$.

\section{Project 389: \\ Geoenvironmental evaluation of coastal belts in Arab countries.}

Geoenvironmental evaluation of the coastal belts in the southern Mediterrenean and Red Sea Arab countrics: processes, management and sustainable development.

Proposers:

Z M Zaghloul and Ferial El Bedewy

Geology Department.

Mansoura University and

Geological Survey of Egypt,

Cairo, Egypt

The project intends to fill a gap in previous IGCP Projects $(61,200$, and 274$)$ by studying and documenting present coastal changes in the Arab countries lying on the southern side of the Mediterranean and Red Sca. The proposed focus in this project is Holocene sea-level changes and the related environmental problems which threaten coastal areas. Altention will be given to coastal topography, geomorphology, climate, oceanography, marine geology, sediment transport, coastal erosion processes and means of protection. natural coastal resources, and pollution phenomena. Serious environmental hazards will be recognised and suitable approaches for protection will be suggested.

The project is accepted for 5 years $(1995-1999)$.

\section{Project 391:}

\section{Sand accumulations and groundwater in the Sahara}

Establishing the relationship between silnd dune-fields and groundwater aquifers in the eastern Sahara by remote sensing.

Proposers:

Farouk El-Bazl and Ibrahim Himida?

1725 Commonwealth Avenue,

Boston MA(02215. USA

2 I Mathal, El-Matariya Street, Cairo. Egypl

Groundwater resources in arid and semi-arid areas are of paramount importance and appropriate and effective techniques of their exploration in a desert environment do not often produce easily comparable results. The project will study the groundwater resources in the eastern Sahara by identilying and delineating buried channels and depressions using satellite images. (iIS (Geographic Information Systems) and ficld work for the ground truth. The project will involve mapping of Holocene fluvial channels and modelling of groundwater potential in the desert. The results should identify targets for the ground truth investigation.

The project is aceepted for 5 years $(1995-1999)$.

\section{Vladislav Babuska}

IGCP Secretary

Division of Earth Sciences

UNESCO Paris

\section{New IGCP Project 381: South Atlantic Mesozoic correlations}

The key objectives of this new project are to promote interdisciplinary and, most importantly, integrated international and intercontinental correlative studies of the Mesozoic sedimentary basins of the South Atlantic Ocean, including its marginal basins in Africa. West Antaretica and Latin America.

New research data will contribute to the erection of a well-defined standard stratigraphical scale for the Mesozoic South Atlantic successions and contribute to our understanding of the nature and sequence of major geological events during the formation of the South Atlantic and the possible global impact of these events, thereby also contributing significantly to the exploration of hydrocarbon and mineral resources in the marginal basins.

The marginal basins along north eastern and equatorial South America, the Caribbean and Central America, and their correlative central and equatorial West African basins (from Angola to the Senegal-Mauritanian and western Morocco basins) will be covered by the project and included as part of the northern South Atlantic. This approach is particularly important as a means of investigating the Cretaceous links between central North Atlantic-western Tethyan provinces and the incipient South Atlantic. For the southern South Atlantic (south of the Rio Grande-Walvis Ridge) the areas from southeastern Brazil. Uruguay. Argentina, southern Chile. West Antarcica and south-western Africa will be covered. The understanding of the early geological and oceanographic links between South America, west Antarctica and Africa demands a thorough investigation of the southernmost sites.

\section{Background to the project}

The Mesozoic sedimentary succession of the South Atlantic marginal and oceanic basins offers an excellent opportunity for major interdisciplinary efforts towards the understanding of processes of basin evolution on passive continental margins. However, despite half a century of intensive geological study, few attempts have as yet been made to integrate data from the various basins into a wider, common geological framework. Stratigraphical events recorded in one basin are rarely correlated beyond the immediate adjacent areas into a more global context. For example, global climatic changes, which exercise a durable and direct imprint on the geological record by controlling biogenic productivity, sediment accumulation rates and biotic distribution trends, are seldom taken into consideration.

A number of features of the geology of the South Atlantic are still poorly understood, such as :

1 the delayed development of fully marine successions as a result of the long-term topographic high created by the Walvis Ridge hot spot to the south and the late separation of the equatorial rift basins in the north-west;

2 the resultant lacustrine mega-systems and the Aptian salt basin, with their characteristic physico-chemistry and influence on global climate;

3 the oceanic circulation patterns in the Late Cretaceous and Palaeogene.

Until recently mainly localised data, such as local seismic grids and the results of geological surveys, were all that were available for correlation work. This has resulted in the current confusion of local names and stratigraphical scales that cannot be systematically related. However, as a result of the creation of regional data sets. such as seismic grids and Seasat gravity 
maps, the past ten years have seen the initial unravelling of the true tectonic framework of the basins.

Unfortunately. progress and understanding on all fronts remain severely hindered by the lack of a rigorous biostratigraphical framework. The establishment of a modern, rigorously controlled stratigraphical framework will provide the means for providing answers to a wide range of local, regional and global corrclation issues.

These include:

1 Pre-Cretaceous, proto-rift events of the southern and northern South Nantic.

2 The time and facies lianework of the Cretaceous rift sequence and the ensuing drift phases. Currently the exale time of onset of the rifting is not known, neither is the exact timing of the drift phase.

3 The rift and drift ties to interior Atrica. interior South Americal and the geoid as a whole. (Unravelling of the apparently relatively simple rift history of the South Atamtic maly ultimately yich the complates needed in order to better understand and model more complex rift margins, such as those of the North Atlantic.)

+ Reliable hiostrallgraphical correlations for testing the radiometrically determined ages of flood basalsi in Braril and Namibiat through the dating ol incrbedded ritt volcanics and sedimentary rocks. A belter understanding of the extent, nature and thermal and topographic influence of the Walvis Ridge hot spor as well as the postulated Niger Dela hot spot will also emeroc

5 The nature and origin of the globally unique Neocomian'- early Aptian fluvio lacustrine mega-systems with their abundance of rich hydrocatbon source rocks. The lakes may have been large enough to exercise global alfects on the biosphere and may provide clues to the Cretaceous waming phase and to dysoxic-anoxic events. The lakes may also contain pre-late Aptian salts and as yet unrecognised evidence of marine phases. (Barremian organic geochemistry suggests early marine links, whilst the first Red Seatype segments of oceanic crust are thought to have formed doring that time.)

6 The nature and origin of the unicpue Aptian salt basin.

7 The effects of the Aptian salt basin on global climate and sea-level changes. (It has been hypothesised that the global Aptian sea level drops on the Exxon chart are related to catastrophic. Messiniantype inundations of desiccated South Atlantic ritt hasins.)

8 The development of the Iate Cretaceous and Palaeogene dysoxic-anoxic cycles: again, the size of the basins does not exclude global warming implications.
9 Following consolidation of the isstes mentioned above, a more precise sequence-stratigraphical framework for the South Atlantic.

For hydrocarbon exploration the consequences are obvious: lower risks and more discoverics through better understanding. If the hydrocarbon reservoirs and migration pathways can be located using a reliable sequence stratigraphy, the proved source rock volumetrics are sufficient to support lar greater reserves.

\section{Research objectives}

In order to reach the project goal the following broad topics will be pursued as primary research tasks:

I To achieve, through international scientific cooperation and joint-ventures of working groups, a fully integrated and refined stratiglaphical and geochronological framework (with regards to biostratigraphy. magnctostraligraphy, geochemistry. seismic stratigraphy, sequence stratigraphy, cyclostratigraphy and event stratigraphy), which can be applied to the Mesozoic mon-marine and marine sequences of the south Allantic, thereby enhancing interbasinal and intercontinental stratigraphical correlation.

2 To provide interdisciplinary stratigraphical data that allow the reconstruction of the palacogeographical and palacocanographical history of the South Atlantic during the Mesozoic

3 To investigate the nature and magnitude of locally recorded geological and biological events and to explain their possible global significance.

\section{Expected results}

The results of the project are expected to be: 1 integrated stratigraphical data sets. comprising intercalibrated biostratigraphical zonation schemes, magnetostratigraphy, sedimentary geochemistry forganic geochemistry. stable isotopes and trace elements). sedimentology, sequence stratigraphy and teconostratigraphy:

2 a high-resolution cvent stratigraphy (bioevents, long-and short-term chemostratigraphical events, custatic Muctuations). testing the synchroncity of regional events and their relationship with teconosedimentary and/or climatically induced variations and global events:

3 integrated regional models of basin development and evolution;

4 a series of regional, evolutionary palacogeographical maps at J:500000scale. from the last phase of Gondwana to the fully oceanic settings at the end of the Mesoroic, showing palaeoenvironments and the general geological and stratigraphical tramework:
5 general palaeogeographical maps of the South Atlantic at 1:10000 (000-scale:

6 biogeographical maps at $1: 10000000$ scale, with the patterns of distribution of important micro- and macrofossil groups for selected time-intervals:

7 palacoceanographical maps at $1: 10000000$-scale, with inferred bot10m and surface circulation patterns:

8 detailed regional models of the geological setting and genesis of known and potential mineral resources, with sections illustrating the different stratigraphical plays. maps of occurrences (at $1: 5000(10)(0)$ and estimates ol reserves.

9 publication of the results of the project. procecdings of working group meetings and special volumes, which will include major interdisciplinary contributions of geological correlation within a regional framework.

\section{Project meetings}

Jilly 1995

Inaugural project meeting in Uberaha.

Minas Gerais, Bravil, in conjunction with the 14th Brarilian Palateontological Congress. The project was introduced to the Latin American scientific commonity at this meeting.

1996 (late Augustearly September)

$\Lambda$ enceral meeting is planned 6 be held in Aracaju, Sergipe, north-eastern Braril. Continental Cretaceous sections are widespread in northern Brasil, from which an abundant reptilian fauna has been recorded. Field trips will be organised to visit some of these sites, as well ats to sample and investigate two typical rilt-phase marginal basins (Recncavo, in Bahia. and Alagoas ) and the Crelaceous marine outcrop record (Sergipe, PernambucoParaiba and Potiguar basins). The 1006 meeting will tocus on ongoing research and the state-of-the-art of geological correlations and the bio-chronosiratigraphical frameworks currently adopted for the South Atlantic Mesozoic sequences. The problems identitied will prompt the proposal of clearly defined research topics and specilic rescarch targess for the fortheoming year(s).

For 1996 a European regional meeting is also being planned, to be held in Germany, simultaneously with the 2 nd European Round Table on the Palateontology and Stratigraphy of South Nmerica.

Provisiomal locations for subsequent annual project meetings are:

1997 Cameroon, (in conjunction with the 13th African Micrepalacontological Colloguium):

1988 Argentina:

1999 Nigeria:

2000 South Africa.

These are all key areas for the understanding of the geological links between west Antarctica. South Americat and Africa, and between the Austral and Tethyan realms. 
We invite all participants of SAMC to send us announcements, descriptions and short reports of current research work, information on projects being planned, underway, or recently completed, which relate to the scope of SAMC, literature reviews, etc. to be published in the project newsletter. References of papers and abstracts in preparation, in press, or recently published will be compiled and listed in each issue. Please report them for inclusion in our newsletters and annual reports, by sending to the SAMC Secretariat a list of your papers in press and four offprints of published papers (of which two will be forwarded to the IUGS/IGCP Secretariat). Comments and discussions of problems within the areas of interest will be especially welcome. For all written communications please submit a printout of the text and a diskette containing the text file in Microsoft Word, WordPerfect, Nisus or ASCII format (Macintosh or IBM/Windows).

Alternatively, texts may be submitted by email to (E Koutsoukos):

bvb5@c53000.petrobras.anrj.br Do not send text for the newsletter by fax.

Anyone interested in participating in SAMC, or needing more information, should write to the SAMC Secretariat (address below) giving the following information: name and full address; telephone, fax, e-mail address; main research interests; a short (maximum half a page) account of current research related to SAMC.

English-speakers should contact

Márcio R Mello

PETROBRAS-Cenpes/Divex/Segeq

Cidade Universitária,

Quadra 7 - Ilha do Fundão

BR-21949-900 Rio de Janeiro, RJ, Brazil

Tel: +55 21 5986460; Fax: 5986799;

e-mail: bv77@c53000.petrobras.anrj.br

French-speakers should contact

Mitsuru Arai

PETROBRAS-Cenpes/Divex/Sebipe

Cidade Universitária,

Quadra 7 - Ilha do Fundão

BR-21949-900 Rio de Janeiro, RJ, Brazil

Tel: +55 21 5986440; Fax: 5986795;

e-mail: bvb5@c53000.petrobras.anrj.br

Eduardo A M Koutsoukos

(Petrobras-Cenpes/Divex/Sebipe, 21949.

900 Rio de Janeiro, RJ, Brazil)

\section{Peter Bengtson}

(Geologisch Palontologisches Institut, Universitt Heidelberg, D-69221 Heidelberg, Germany)

\section{EuroGeoSurveys}

The national geological surveys of the European Union* have recently signed a formal agreement to form an Association known as EuroGeoSurveys. The purpose of this body is to

- jointly address European issues of common interest;

- promote the contribution of geosciences to European Union affairs and programmes;

- assist the European Union to obtain technical advice from the members of the Association and

- provide a permanent network between the Geological Surveys.

EuroGeoSurveys will undertake activities in the public domain of the European Union that will benefit most from the combined and coordinated expertise of its member Surveys. EuroGeoSurveys will also act in response to specific requests from the European Union, and will be involved in formulating proposals for actions of interest to the European Union, both within Europe and elsewhere.

EuroGeoSurveys will have available the expertise of more than $6000 \mathrm{staff}$ in the 15 countries of the Union. Dr Peter J Cook, Director of the British Geological Survey, is the President of EuroGeoSurveys. Dr C Staudt, Director of the Dutch Geological Survey, and Mr J O Carlsson, Director of the Swedish Geological Survey, will be VicePresidents. Dr R N Annells will be the Secretary General and will have a permanent office in Brussels commencing on 1 January 1996.

*Austria, Belgium, Denmark, Finland, France, Germany, Greece, Ireland, Italy, Luxembourg, The Netherlands, Portugal, Spain, Sweden and the United Kingdom

Dr P J Cook

British Geological Survey

Keyworth

Nottingham, UK

\section{Fortune Head plaque unveiled}

From Geolog via GAC-Paleontology Division Newsletter no. 38

A plaque marking the Precambrian-Cambrian boundary global stratotype (Episodes, v. 17, nos. 1 and 2, pp. 3-8) has been unveiled at the opening ceremonies of the Fortune Head Ecological Reserve, in Fortune,

Newfoundland. The plaque was placed at Fortune Head by the Provincial Parks

Division and the Canadian National Committee for IGCP.

The plaque was unveiled at the Fortune Lions Club, following speeches by Don Hustins (Director, Provincial Parks), David Genson (Secretary-Treasurer, IGCP Canadian National Committee), Wilf Dyke (Wilderness and Ecological Reserves Advisory Council) and Mike Anderson (Memorial University, retired)who was involved in the selection of Fortune Head as the global stratotype two years ago. Mike Anderson briefly outlined the geological significance of the site, explaining why it was such a good point for the global stratotype, and the change of body fossils and trace fossils management of ecological reserves (which, in theory, allows collection of fossils under permit). Mike emphasised that collection of fossils should never be allowed here, and he expressed concern about the regulation of this, and two other geologically based ecological reserves in the Province.

Amongst those of us making the effort to examine the actual boundary point was an intrepid reporter from the Southern Gazette. For a while it seemed that the combined efforts of five distinguished geologists (including at least two palaeontologists) would fail to locate a Phycodes pedum trace fossil to show her. However, we were saved by Dave Benson, and we later had the opportunity to examine better examples, higher in the sequence.

The brief wording on the plaque explains the significance of the site which is now recognised by provincial agencies, protected from development, and awaits visits from any and all interested parties.

\section{Dave Liverman}

Natural Resources Department, Government of Newfoundland

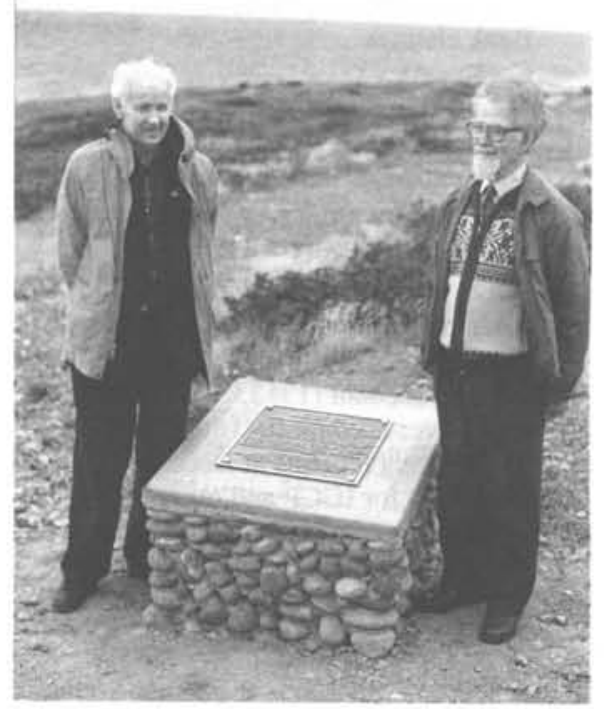

David Benson (left) and Mike Anderson (right) at the plaque. 


\section{IUGS financial statement for 1994 and budget for 1995 (US\$)}

1994

\author{
21200.00 \\ 133000.00 \\ 0.00 \\ 3000.00 \\ 8000.00 \\ 226400.00 \\ 9000.00 \\ 80000.00 \\ 57240.47 \\ 57000.00 \\ 7170.44 \\ 307.99 \\ 5288.71 \\ $2555 .(00$
}

Gain on exchange

Total:

Carry-over from 1994101995

Total receipts

2 Expenditure

2.1 Scientific activities

IUGS Commissions, Boards. Committees. Working Groups (Schedule A)

Rescarch projects

- IGCP projects

- Circum-Atlantic Programme

- GARS'

- Deposil Modelling

- Climates of the Past

- Inter-Union Commission on the Lithosphere

- Working Group on Landslides

- ICSU Programs

Grants 10 affiliated organizations (Schedule B)

IUGS comtribution to

- ICSU

- ICSTI

2.2 Meetings, conferences

Routine meetings

Scientific meetings

2.3 Publications

Episodes 5

2.4 Administrative expenses

Operating costs and stipplies

Miscellaneous expenses. audit

Bank charges

Contingency

Total expenses

Transfer to reserve account ${ }^{\prime \prime}$

Total expenses including transfer to reserve account

3 Excess of income over expenditure

4 Status of accounts

4.1 IUGS operational account

Accumulated cash balance at January 1, 1994

Accumulated cash balance at December 31. $1994^{7}$

-Reston account (13133.17)

- Hannover account (64169.32)

610162.61

62821.58

270.300 .00

3100.00

10000.00

15000.00

13000.00

20000.00

15600.00

12000.00

7052.00

562.74

21330.86

2708.14

45000.00

1500.00

8878.81

3593.97

0.00

512448.10

97714.00

82675.47

77302.49

34.500 .00

34500.00

43000.00

16358.08

(t)

UNESCO for IGCP and other contracts

Excess of receivable over payable

4.2 IUGS reserve account

Transfer to reserve account

4.3 Hutchison fund

Status of account
1995

19700.00

1.39800 .00

10000.00

$9(0) 0.00$

4000.00

240000.00

$90(0) .00$

80000.00

$57000.00^{3}$

5000.00

573.500 .00

19200.00

592700.00

70250.00

281800.00

0.00

19000.00

17000.00

17000.00

20000.00

1000.00

$3.3900 .000^{+}$

12000.00

7405.00

600.00

25000.00

3000.00

45000.00

2000.00

8000.00

4000.00

15745.00

582700.00

10000.00

592700.00

4. 4 'Trondheim account" 


\section{Notes on the 1994 financial statement}

The financial statement is based on the ICSU guidelines and gives information about the IUGS accounts in Hannover and Reston; it does not include the local currency account in Moscow.

$1 \cdot 50$ projects were funded by UNESCO in 1994. Fight of these 50 projects have been decentralised. i.e. the funds have beentransferred directly from UNESCO to the respective project leaders.

- The UNESCO payment for GARS was transferred directly by UNESCO in 1994.

- The $\$ 3000$ contribution to Deposit

Modeling is the final payment for the year 1993

- The UNESCO payment in the amount of $\$ 8.000$ for Climates of the Past (CLIP) is the linal payment for the year 1993.
2 Member countries pay annual contributions according to their selected category of membership as outlined in the following table:

$\begin{array}{lllllllll}\text { Category } & 1 & 2 & 3 & 4 & 5 & 6 & 7 & 8\end{array}$ $\begin{array}{llllllll}\text { Contribution* }^{1} & 2 & 4 & 7 & 12 & 29 & 35 & 70\end{array}$

* valued at US $\$ 400.00$ per unit as of July 15, 1989. According to the decision of the IUGS Council at its meeting in Washington in July 1989 , all countries delinquent in paying their annual dues for more than two years will be deemed inactive. To regain active status, dues for the current year plus previous two years must be paid. All other previous pending dues will then be waived automatically. At December 31, 1994, outstanding payments of active members totalled $\$ 44000$.
3 The UK contribution to IGCP for the year 1995 was received during 1994 as an advance payment.

4 Including carry-over from the year 1994 in the amount of 14.200 .

5 IUGS payments to Episodes represent support for printing and related costs.

6 Transfer to reserve account for the year 1994 see item 4.2.

7 Includes carry-over of ICSU programs from the year 1994 in the amount of $\$ 14.200$ and IGCP funds in the amount of $\$ 5.000$.

8 Investment in security bonds, the exact value of which will be given when payment is duc.

91994 expenses were paid by the Geological Survey of Norway.

\section{Schedule A Payments to Commissions}

\begin{tabular}{lr} 
& 1994 \\
\cline { 2 - 2 } COGEOINF( & 10000.00 \\
INHIGEO & 4000.00 \\
Marine Geology & 5000.00 \\
Systematics in Petrology & 10260.00 \\
COMTEC & 3000.00 \\
Stratigraphy & 20000.00 \\
Global Sedimentary Geology & 6000.00 \\
COGEOED & - \\
Fossil Fuels & 2000 \\
COGEOENVIRONMENT & 1000.00 \\
ABRD & 1384.02 \\
ABP Total & 177.00 \\
\multicolumn{1}{c}{ AB } & 62821.58
\end{tabular}

\section{Igneous data base accessible on the Internet}

An international igneous data base, IGBADAT, has been assembled over the last few years under the initial leadership of $F$ Chayes, and now of the undersigned, taking into account the recommendations of the Subcommission on Data Bases for Petrology (SDBP).

The last update (5.1) contains 19519 specimen descriptions in 1066 groups. The attached IGBAREF file consists of 1357 references. FORTRAN programs are also included to manage the base. The base contains a wide range of information in severat languages covering geographical. geological, chemical, age, petrological, mineralogical and other additional information (Brändle and Nagy, 1995). The database is open to anybody for use in scientific applications.

The data and reference file, necessary description and FORTRAN programs to facilite the utilisation of the base are in standard ASCII files. Originally only available on magnetic media, the base is now available via the Internet.

\section{Connection:}

FTP olmo.csic.es

login/password anonymous

ed pub/igneous

Files:

readme.txt ( 16153 bytes)

igba.zip ( 1683193 bytes) compressed file structur.txt ( 143231 bytes)

The zip files can be uncompressed with unzip program in PC or Unix, VMS system. Machintosh users should use Stuffit Expander and Dropstuff Expander. Unfortunately, the data base is far from complete or even representative of the enormous quantity of published data. Updating is continuing under the aegis of SDPB but new, volunteer contributors are welcome.
Schedule B Affiliated Organizations

\begin{tabular}{|c|c|}
\hline 1994 & budget 1995 \\
\hline 3000.00 & 3000.00 \\
\hline 2500.00 & 2500.00 \\
\hline 2500.00 & 3500.00 \\
\hline 2000.00 & - \\
\hline 2000.00 & - \\
\hline - & 1000.00 \\
\hline - & 1000.00 \\
\hline - & 1000.00 \\
\hline 12000.00 & 12000.00 \\
\hline
\end{tabular}

The CSIC of Spain supports the server of the communication via Internet
References
Brandle, $J$ L, and Nagy, G, 1995, The state of the 5th version of IGBA: Igneous Petrological Data Base: Computers and Geosciences v. 21 . no. 3 pp. $425-432$.
Information about Internet may be found in Computers and Geosciences (1995) v. 21/6.

\section{J L Brändle}

Chairman SDBP

Dep. Petrologia y Geoquímica

Fac. Ciencias Geológicas

28040 Madrid, Spain.

e-mail:brandle@uecmax.sim.ucm.es or igelbol@pinarl.csic.es

\section{G Nagy}

Secretary SDBP

Lab. Geochemical Research

Hugary Academy of Sciences

112 Budapest Budaörsi ut 45, Hungary

e-mail:H4077nag@clla.hu 